\title{
The aryl hydrocarbon receptor is a modulator of anti-viral immunity
}

\author{
Jennifer L. Head ${ }^{\star}$ and B. Paige Lawrence ${ }^{\star}, \#, 1$ \\ * Departments of Environmental Medicine, University of Rochester School of Medicine and Dentistry \\ Rochester, NY 14620 USA \\ \# Departments of Microbiology and Immunology, University of Rochester School of Medicine and Dentistry \\ Rochester, NY 14620 USA
}

\section{Abstract}

Although immune modulation by AhR ligands has been studied for many years, the impact of AhR activation on host defenses against viral infection has not, until recently, garnered much attention. The development of novel reagents and model systems, new information regarding antiviral immunity, and a growing appreciation for the global health threat posed by viruses have invigorated interest in understanding how environmental signals affect susceptibility to and pathological consequences of viral infection. Using influenza A virus as a model of respiratory viral infection, recent studies show that AhR activation cues signaling events in both leukocytes and non-immune cells. Functional alterations include suppressed lymphocyte responses and increased inflammation in the infected lung. AhR-mediated events within and extrinsic to hematopoietic cells has been investigated using bone marrow chimeras, which show that AhR alters different elements of the immune response by affecting different tissue targets. In particular, suppressed $\mathrm{CD} 8^{+} \mathrm{T}$ cell responses are due to deregulated events within leukocytes themselves, whereas increased neutrophil recruitment to and IFN- $\gamma$ levels in the lung result from AhR-regulated events extrinsic to bone marrow-derived cells. This latter discovery suggests that epithelial and endothelial cells are overlooked targets of AhR-mediated changes in immune function. Further support that AhR influences host cell responses to viral infection are provided by several studies demonstrating that AhR interacts directly with viral proteins and affects viral latency. While AhR clearly modulates host responses to viral infection, we still have much to understand about the complex interactions between immune cells, viruses, and the host environment.

\section{Keywords}

Influenza Virus; Neutrophils; T cells; Immune response; Lung

\footnotetext{
1To whom correspondence should be addressed: B. Paige Lawrence, University of Rochester School of Medicine and Dentistry, 575 Elmwood Ave, Box 850, Rochester, NY 14642, (585) 275-1974; paige_lawrence@urmc.rochester.edu.

Publisher's Disclaimer: This is a PDF file of an unedited manuscript that has been accepted for publication. As a service to our customers we are providing this early version of the manuscript. The manuscript will undergo copyediting, typesetting, and review of the resulting proof before it is published in its final citable form. Please note that during the production process errors may be discovered which could affect the content, and all legal disclaimers that apply to the journal pertain.
} 


\section{Anti-viral host defenses are important targets for modulation by environmental factors}

Numerous preventive and therapeutic agents have been developed, yet viral infections continue to pose a significant and persistent health threat, causing substantial morbidity, mortality and socioeconomic losses worldwide [1,2]. Respiratory infections are among the top 10 leading causes of death, and common respiratory pathogens such as influenza viruses have the potential to cause pandemic illness. Although the past 20 years has seen tremendous advances in our understanding of immune responses to viral infection, we still do not fully understand why there are differences among individuals in susceptibility to and pathophysiological consequences of viral infection.

Many differences in susceptibility can be attributed to gender, age, and host genetics [3]. However, these factors alone are not sufficient to account for variation among individuals infected with the same viral subtype. Thus, additional elements likely influence host responses and clinical outcomes following infection. There is mounting evidence that environment and exposure to pollutants are important but overlooked factors that influence responses to viral infection [4-7]. For many types of pollutants some facets of immunotoxicity have been considered, but an impact on host defenses against viral infection has not been explicitly examined. However, for pollutants that contain AhR ligands data from multiple experimental systems collectively demonstrate clear immunomodulatory effects, including alterations in responses to viral infection. Several epidemiological reports show that exposure to environmental contaminants that contain AhR ligands correlates with increased incidence of respiratory infections and alterations in immune cell function [8-12]. Moreover, studies using rodent models show that exposure to AhR ligands impairs host resistance to viral infection. For example, mice exposed to TCDD have a decreased ability to survive infection with herpes virus type II [13], coxsackie virus B3 [14], and influenza A viruses [15-18]. In fact, decreased host resistance to influenza A virus is often touted as one of the most sensitive adverse effects of TCDD; however this depends upon many factors, including viral subtype and level of exposure [19].

The focus of this review will be to explore existing evidence that environmental signals delivered via the AhR influence anti-viral immune defenses. The majority of information regarding how AhR modulates the immune response to viral infection comes from studies using mouse models of infection with human influenza A virus. Therefore, much of this review will focus on this experimental system, with particular emphasis on new developments in our understanding of direct targets of AhR action. To put these research findings into broader context, a brief review of the key elements in play during infection with influenza virus is provided. We will also discuss information from other viral models, identify gaps in our knowledge, and suggest approaches to delineate more precisely how AhR modulates anti-viral immune responses.

\section{Infection with influenza virus stimulates innate and adaptive immune responses, which result in viral clearance}

When influenza viruses enter the respiratory tract, they trigger a series of events that, in an immune competent individual, lead to the successful clearance of the virus (Figure 1). This response is initiated by respiratory epithelial cells, which, in addition to serving as a physical boundary between the host and environment, initiate the host's response to infection. Primary infection causes rapid leukocyte infiltration and the release of numerous cytokines and chemokines. Although different signals regulate the extravasation of specific cell types across endothelial and epithelial barriers, the result is that leukocytes migrate into the lung in two 
distinct phases: an early or innate response and a later or adaptive response. The innate immune response involves the recruitment of macrophages, neutrophils and natural killer (NK) cells, which are found in the lung within 12-48 $\mathrm{h}$ of infection, and persist for 5-7 days. Although they utilize distinct mechanisms to accomplish their job, macrophages, neutrophils and NK cells kill infected cells and release chemoattractive and inflammatory mediators that stimulate activation and recruitment of additional cells [20].

The activation of respiratory dendritic cells (DCs) is another critically important innate response to viral infection. DCs take up viral antigens and migrate to draining lymph nodes, where they present viral peptides to $\mathrm{CD}^{+}$and $\mathrm{CD}^{+} \mathrm{T}$ lymphocytes in the context of MHC class I and class II molecules [21-23]. When properly activated by DCs, virus-specific T cells clonally expand and differentiate into virus-specific effector $\mathrm{T}$ cells. $\mathrm{CD} 8^{+} \mathrm{T}$ cells differentiate into cytotoxic T lymphocytes (CTL), which can be detected in the lung starting about 6-7 days after infection [16,24], but they don't reach peak levels in the lung until 8-10 days after infection, a timeframe that correlates with complete viral clearance $[25,26]$. While virusspecific $\mathrm{CD} 8^{+} \mathrm{CTL}$ emigrate to lung and directly kill infected cells, virus-specific $\mathrm{CD} 4^{+} \mathrm{T}$ cells do not directly kill infected cells. Instead, they facilitate the generation of memory $\mathrm{CD} 8^{+} \mathrm{T}$ cells and direct $\mathrm{B}$ cell activation and antibody isotype switching [27-29]. Virusspecific antibodies are formed during a primary response, but their essential function is immune protection against repeated infection.

After the virus is cleared, a small pool of memory lymphocytes remains in the lung and lymphoid organs. When the same or antigenically similar viral strain is encountered again, these memory lymphocytes provide rapid protective immunity. It is generally considered that $\mathrm{CD} 8^{+} \mathrm{CTL}$ are the principal means for viral clearance and host resistance in a primary infection, whereas both virus-specific antibodies and $\mathrm{CD} 8^{+} \mathrm{CTL}$ are important during memory responses $[27,29,30]$. Disruption of any aspect of these responses can have a significant and detrimental impact on clinical outcomes following respiratory viral infection. Unchecked stimulation of innate responses can cause excessive damage to healthy tissue, and insufficient activation of lymphocytes can result in impaired viral clearance, reduced formation of memory lymphocytes, and lower levels of protective antibodies. Thus, it is by working together in a properly tuned system that innate and adaptive immune responses provide effective protection from primary and repeated viral infections.

\section{AhR is a known immune modulator}

Immune suppression by AhR ligands, such as TCDD, has been studied for many years and several recent reviews provide comprehensive summary of this literature [31,32]. Yet, it is important to recall several aspects of immune modulation by AhR ligands. First, AhR is expressed in bone marrow-derived cells such as $\mathrm{T}$ and B lymphocytes, neutrophils and macrophages, and findings generated using AhR-deficient mice indicate that the immunomodulatory effects of TCDD are AhR-mediated [26,32-34]. While the exact mechanism of AhR-mediated immunomodulation is unknown, the cannonical pathway of AhR activation is well characterized. In this pathway, AhR ligands, such as TCDD, bind to the receptor in its inactivated state in the cytosol. Once bound by ligand, the receptor translocates into the nucleus and dimerizes with the aryl hydrocarbon receptor nuclear translocator (ARNT). This heterodimer then interacts with aryl hydrocarbon responsive elements (AhREs) in the enhancer of AhR target genes, promoting the transcription of genes such as the drug metabolizing enzymes Cyp1a1 and Cyp1b1 [35]. Second, AhR-dependent changes in immune function are not limited to TCDD, as other AhR ligands, such as certain polychlorinated biphenyls and polyaromatic hydrocarbons, cause similar immunomodulatory effects [31,32, 36]. Whether or not AhR-deficient $\left(\mathrm{AhR}^{-l-}\right)$ mice have alterations in immune system development and function is an area of active research, and likely depends upon the specific 
strain of mouse and facet of the immune system being studied [26,32-34,37,38]. For example, mice deficient in AhR have been shown to have different B cell maturation profiles compared to wild-type mice; however, the functional effects of these differences have yet to be defined [39]. Despite these gaps in knowledge, it is clear that the immune system is sensitive to modulation by AhR. With regard to anti-viral immunity, AhR ligands have been reported to impact various aspects of the response to viral infection, which are summarized in the following sections. The specific consequences vary among the different viruses and model systems used; however the fundamental message is clear: AhR activation modulates components of the response to viral infection.

\section{AhR activation alters innate responses to influenza virus infection}

AhR activation decreases survival from infection with a non-lethal dose of influenza A virus $[15,16]$. Others have reported similar effects on host resistance using lethal viral challenges $[17,18,40]$. Initially, it was postulated that decreased survival was due to an inability to clear virus; however, TCDD-treated mice clear virus from their lungs with kinetics similar to controltreated mice, and there is no change in the overall pulmonary viral burden [17,41,42]. In fact, some studies have shown that influenza A virus replication may actually be inhibited by neutrophil recruitment $[43,44]$, however whether or not this inhibition is affected by AhR activation remains unknown. These findings suggest that other mechanisms underlie the decreased survival from influenza virus infection. One likely mechanism is the increased recruitment of neutrophils to the lung. Compared to infected controls, about twice as many neutrophils are found in the lungs of infected mice treated with TCDD (Figure 2A). Excess neutrophils are observed in airways and lung interstitium of TCDD-treated wild-type mice, but are not observed in lungs of TCDD-treated $\mathrm{AhR}^{-1-}$ mice [33].

This increase in neutrophils is of great interest for several reasons. During uncomplicated respiratory viral infection, the recruitment of neutrophils to the lung is commonly observed; however, excessive accumulation of neutrophils during infection has been linked to immunemediated pathology and death [45-49]. For example, recent reports suggest that during the 1918 Spanish influenza pandemic, uncontrolled neutrophilia was associated with mortality from influenza-related complications [46]. Neutrophil recruitment has also been implicated in the acute pathology of other viral infections such as respiratory syncytial virus (RSV), herpes simplex virus-1 (HSV-1) and cytomegalovirus (CMV) [45,47-49]. What factors trigger heightened pulmonary neutrophilia during viral infection remain uncertain; but recent findings suggest that controlling neutrophil recruitment may provide an important but overlooked means to improve clinical outcomes during viral infection $[36,44,46,50]$.

Not only has the relationship between excessive neutrophil recruitment to the lung and enhanced immune-mediated pathology been demonstrated in other systems, it has been established that AhR-mediated excessive neutrophil recruitment contributes to decreased survival and more severe bronchopneumonia in TCDD-treated, infected mice [33]. Moreover, this effect of TCDD on neutrophil recruitment may not be unique to the response to influenza virus, as it has been reported in model systems using non-infectious antigens, in which excessive neutrophilia is observed at the site of antigen challenge [51-53]. However, the type of antigen likely influences the nature of AhR-mediated changes in neutrophil recruitment, as TCDD-treated mice infected with Streptococcus pneumoniae have markedly reduced neutrophil recruitment compared to vehicle-treated mice [54]. Differences in the consequences of AhR activation during infection with influenza virus and $S$. pneumonaie may be explained by the action of pattern recognition receptors (PRRs), which recognize different types of pathogens and activate distinct pro-inflammatory signaling pathways [55]. It is possible that AhR activation impacts neutrophil recruitment by modulating signaling pathways important for PRR function or expression, but this concept has yet to be experimentally tested. 
Nevertheless, it is becoming clear that AhR activation impacts pathways that control neutrophil migration, and as we decipher the underlying mechanism new targets for regulating neutrophil trafficking may be revealed.

An important new concept to emerge from these studies is that AhR specifically targets regulatory pathways that are involved in the host's response to infection, such that they are primed to respond inappropriately. The basis for this idea stems from the observation that, in the absence of infection, AhR activation does not alter the number of neutrophils at the site of antigen challenge [16,33,51-54]. This suggests that AhR activation synergizes with or potentiates infection-associated signals important for neutrophil recruitment. Within the context of infection with influenza virus, we have systematically examined mechanisms by which AhR could mediate an increase in the number of neutrophils in the lungs of infected mice. While infection increases the expression of soluble chemoattractants in the lung, TCDDtreatment does not further enhance the levels of these molecules [33,56]. Furthermore, treatment with TCDD does not increase expression of adhesion molecules on neutrophils, endothelial or epithelial cells in the lung [33]. Also unaffected by AhR activation are the number of circulating neutrophils, their function, or the level of neutrophil death in the lung $[33,56,57]$. Thus, it is likely that AhR activation during viral infection targets a novel pathway for neutrophil recruitment, which has yet to be identified.

While AhR activation does not affect the levels of known neutrophil chemoattractants, it does increase levels of the important anti-viral cytokine interferon (IFN)- $\gamma$ in the lungs of mice infected with influenza virus (Figure 2B). However, the number of neutrophils in the lung is the same in infected wild-type and IFN- $\gamma$-deficient mice treated with TCDD. This indicates that elevated IFN- $\gamma$ levels do not underlie the increased recruitment of neutrophils [56]. Instead, we have recently discovered that it is the neutrophils themselves that produce much of the excess IFN- $\gamma$ in the infected lung [58], which suggests that AhR-mediated increases in IFN$\gamma$ levels may be due to the elevated number of IFN- $\gamma$ producing cells rather than a direct impact on IFN- $\gamma$ gene expression.

Interestingly, in the same timeframe in which pulmonary neutrophilia and IFN- $\gamma$ levels are increased, there is enhanced expression of inducible nitric oxide synthase (iNOS) in the lung. AhR-mediated increases in iNOS are observed in alveolar macrophages as well as lung epithelial cells, suggesting AhR targets immune and non-immune cells of the lung. Increased iNOS expression has been associated with influenza-mediated pathology, and its product, nitric oxide (NO), has been implicated as a mediator of both beneficial and detrimental effects during viral infections [58-62]. Similar to increases in neutrophil recruitment and IFN- $\gamma$ levels in the lung, AhR activation alone is not sufficient to induce iNOS. A second signal, in this case viral infection, appears to be required, which again suggests AhR influences the nature of the response to viral infection. One explanation for increased iNOS is that it is downstream of elevated IFN- $\gamma$, which is a known inducer of iNOS expression [63]. However, recent studies using iNOS-deficient mice revealed that AhR-mediated excesses in IFN- $\gamma$ production during influenza virus infection requires iNOS expression [58]. Therefore, it appears that AhRactivation stimulates a novel, iNOS-dependent pathway for IFN- $\gamma$ production in the lung by neutrophils. These findings also highlight iNOS as a potentially new AhR target gene.

\section{AhR activation suppresses adaptive immune responses to infection with influenza $A$ virus}

During primary infection, AhR activation with TCDD profoundly suppresses the clonal expansion and differentiation of influenza virus-specific $\mathrm{CD}^{+} \mathrm{T}$ lymphocytes (Figure $2 \mathrm{C}$ ). Reduced clonal expansion of virus-specific $\mathrm{CD} 8^{+} \mathrm{T}$ cells correlates with diminished virusspecific cytolytic activity and fewer CTL in the lung [26, 32, 64, 65]. In addition to acquiring 
the ability to kill virus-infected cells, activated CD8 $8^{+}$T cells make IFN- $\gamma$, which plays an important role in cell-mediated immunity to viral infection [66, 67]. Exposure to TCDD reduces the number of $\mathrm{CD}^{+} \mathrm{T}$ cells that produce IFN- $\gamma$ and decreases the level of IFN- $\gamma$ produced by cells in the lymph node, providing yet another indicator of suppressed $\mathrm{CD} 8^{+} \mathrm{T}$ cell differentiation (Figure 2D) [64]. Recent studies show that the response of CD8 ${ }^{+} \mathrm{T}$ cells is impaired by an indirect mechanism, because isolated $\mathrm{CD} 8^{+} \mathrm{T}$ cells from $\mathrm{AhR}^{-1-}$ mice remained sensitive to TCDD-induced suppression when adoptively transferred into congenic $\mathrm{AhR}^{+/+}$ recipients [26]. Thus, events within accessory cells that direct the activation of virus-specific $\mathrm{CD} 8^{+} \mathrm{T}$ cells are likely direct targets of AhR ligands, and deregulated function of these cells results in the impaired response of $\mathrm{CD}^{+} \mathrm{T}$ cells during influenza virus infection. Current understanding of mechanisms by which AhR modulates $\mathrm{T}$ cell function is reviewed in this same issue and will therefore not be reviewed here ${ }^{2}$.

Other aspects of the adaptive immune response to viral infection affected by AhR activation are the increase in the number of $\mathrm{CD} 4^{+} \mathrm{T}$ cells in the lymph node and lung, and the production of influenza virus-specific antibodies by B cells. Similar to the clonal expansion of CD8 ${ }^{+} \mathrm{T}$ cells, the number of $\mathrm{CD}^{+} \mathrm{T}$ cells increases upon infection, and exposure to TCDD decreases this response [41]. The significance of this reduction is not yet clear. During primary infection, the generation of influenza virus-specific $\mathrm{CD} 8^{+} \mathrm{CTL}$ does not require the presence of $\mathrm{CD} 4^{+} \mathrm{T}$ cells; however, $\mathrm{CD}^{+} \mathrm{T}$ cells are essential for antibody isotype switching and help to generate and maintain immunological memory (including anti-viral memory $\mathrm{CD}^{+} \mathrm{T}$ cells) [68-70]. Therefore AhR-mediated decreases in the response of $\mathrm{CD} 4^{+} \mathrm{T}$ cells likely impact these important aspects of anti-viral immunity. In support of this idea, levels of virus-specific IgG subtypes are significantly reduced in infected, TCDD-treated mice [16,40,71]. Although the mechanism by which AhR modulates B cell activation and antibody production is not entirely clear, B cells are probably directly affected, and reduced IgM and IgG levels are regularly observed after in vivo and in vitro exposure TCDD and other AhR ligands [19,72-75]. In contrast to the reduction in IgM and IgG levels, virus-specific IgA levels are elevated by TCDD exposure. The increase in IgA levels is probably not unique to the response to influenza virus, as it has been reported in rats and humans following exposure to TCDD $[8,76]$. However it is not known how AhR activation causes this increase.

After the resolution of a primary influenza virus infection, a pool of memory lymphocytes remain, which upon re-infection quickly respond and clear the virus more rapidly than during a primary infection. Given that AhR activation suppresses the primary immune response, it is logical to expect a reduced pool of memory cells. Indeed, this appears to be the case. A single dose of TCDD during primary infection reduces the number of virus-specific memory CD8 ${ }^{+}$ T cells by about $50 \%[26,71]$. This decrease is likely a direct result of the reduced differentiation of virus-specific $\mathrm{CD} 8^{+} \mathrm{T}$ cells during primary infection, but does not substantially impact the responsive capacity of the memory $\mathrm{CD} 8^{+} \mathrm{T}$ cells generated. In other words, AhR-mediated differences in memory $\mathrm{CD} 8^{+} \mathrm{T}$ cells are not due to obvious defects in function, but rather a reduced number of these cells [26]. As a result, although the population of memory cells is significantly decreased, secondary viral infection is cleared from the lungs. While the impact of AhR activation on the generation or function of virus-specific memory $\mathrm{CD} 4^{+} \mathrm{T}$ cells has not been explicitly examined, exposure to TCDD reduces the production of influenza virusspecific IgG [16,40,71]. Similar to effects on CD8 ${ }^{+} \mathrm{T}$ cells, the effects of TCDD on antibody levels are persistent, and upon re-infection the rise in virus-specific $\operatorname{IgG}$ is delayed by over a week [71]. In contrast, virus-specific IgA levels are elevated during primary infection and relatively unaffected upon recall challenge. While it is clear that AhR activation affects the function of B lymphocytes, how these alterations in virus-specific antibody profiles affect host

\footnotetext{
${ }^{2}$ Note to Editorial Staff: Our intention is to refer the reader to Nancy Kerkvliet's article that will be in this same issue. Thanks.
} 
protective memory and vaccine efficacy has not been fully explored. Furthermore, although mice infected with rodent-adapted strains of influenza virus were able to survive a second infection, these studies were conducted using relatively mild, laboratory adapted viral strains. Given that influenza viruses continue to evolve as a result of spontaneous point mutations, genetic reassortment, and interspecies transmission, AhR-mediated reductions in memory responses may become relevant considerations in the context of newly emerging strains of virus; however to date this has not been addressed.

\section{AhR activation does not impair viral clearance from the lung}

Another interesting observation is that AhR activation by TCDD does not result in higher pulmonary viral titers $[17,41,42]$. At least in the context of primary infection, this is probably not due to elevated IgA levels because this is not observed until after viral clearance has been achieved. Instead, viral clearance is likely mediated by a combination of other mechanisms. We have shown that although greatly reduced in number, the few CTL that get to the lung in TCDD-treated mice are able to kill virus-infected cells [42]. This suggests that even though reduced in number, CTL are produced and can eliminate virus-infected cells from the lung. Additionally, AhR activation during influenza virus infection increases the recruitment of neutrophils to the lung and increases in the levels of IFN- $\gamma$ and iNOS expression in the lung. Although not classically considered as host defenders during viral infection, neutrophils directly and indirectly reduce lung viral burden $[36,44,77]$. Likewise, IFN- $\gamma$ and iNOS have been shown to stimulate anti-viral mechanisms and contribute to host resistance to viral infection $[60,78]$. Thus, despite profound reduction in adaptive responses to infection, virus is likely cleared from the lung by a combination of innate and adaptive mechanisms. When put into the context of public health, the collective action of these redundant host protective mechanisms provides good news: even in the face of profound suppression of adaptive immunity, viral clearance can be achieved. Again, the caveat is that these studies were conducted using relatively mild, mouse-adapted strains of virus. This concept has not been tested with other strains of influenza virus, or in other models of viral infection.

\section{AhR activation has direct and indirect effects on leukocyte function}

To determine the mechanism that underlies AhR-mediated modulation of innate and adaptive immune responses during primary infection with influenza A virus, $\mathrm{AhR}^{-/-} \rightarrow \mathrm{AhR}^{+/+}$bone marrow chimera mice were generated. Use of this experimental approach has revealed that AhR activation disrupts immune function both directly and indirectly. TCDD-mediated suppression of the expansion and differentiation of influenza virus specific $\mathrm{CD} 8^{+} \mathrm{T}$ cells requires the presence of $\mathrm{AhR}$ in bone marrow derived cells (Figure 3A,B). When combined with data showing that AhR activation does not affect $C D 8^{+} \mathrm{T}$ cells directly, these findings indicate that AhR targets an accessory cell type within the immune system that is critical for $\mathrm{CD} 8^{+} \mathrm{T}$ cell activation. DCs are an important accessory cell type and are critical for activating naïve $\mathrm{CD} 8^{+} \mathrm{T}$ cells [78]. Although not examined in the context of viral infection, AhR ligands impact DC phenotype, function and number in other model systems [79-85] suggesting that decreased DC function or number could explain suppression of CD8 $8^{+} \mathrm{T}$ cell responses. Another possible direct target for AhR that could adversely affect $\mathrm{CD} 8^{+} \mathrm{T}$ cell expansion are $\mathrm{CD} 4^{+} \mathrm{CD} 25^{+}$regulatory $\mathrm{T}$ cells $\left(\mathrm{T}_{\text {reg }}\right)$. AhR activation by several different ligands has been reported to impact the differentiation and development of $\mathrm{T}_{\text {reg }}$ as well as IL-17 producing $\mathrm{T}$ helper cells (Th17 cells) [86-90]. Although knowledge of $\mathrm{T}_{\text {reg }}$ and $\mathrm{Th} 17$ cell function during influenza virus infection is limited, there is growing evidence that regulatory $\mathrm{CD} 4^{+} \mathrm{T}$ cell subsets play an important role in controlling $\mathrm{CD}^{+} \mathrm{T}$ cell responses to other viruses [91, 92]. Thus, in addition to DC, AhR-mediated alterations in the function of regulatory $\mathrm{CD} 4^{+} \mathrm{T}$ cell subsets could affect $\mathrm{CD} 8^{+} \mathrm{T}$ cell expansion during influenza virus infection. 
In contrast to suppression of $\mathrm{CD} 8^{+} \mathrm{T}$ cell function, $\mathrm{AhR}$ activation in bone marrow-derived cells is not required for TCDD treatment to increase neutrophil recruitment to and IFN- $\gamma$ levels in the lung during influenza virus infection (Figure 3C-F). This suggests that signaling pathways within cells extrinsic to the immune system are also targets of AhR activation, and that AhR's affects on these non-hematopoietic targets have profound consequences on innate immune responses. Furthermore, AhR-mediated iNOS expression, which has been shown to be important for AhR-mediated increases in IFN- $\gamma$ production by neutrophils, is enhanced in structural cells of the lung even when AhR is absent from bone marrow derived cells [58]. Therefore, the search for the mechanism underlying AhR-mediated increases in innate responses, such as neutrophil recruitment, IFN- $\gamma$ production and iNOS expression, should focus on non-hematopoietic cells. In the context of infection with influenza virus, likely nonhematopoietic cellular targets of AhR ligands include lung epithelial cells and pulmonary endothelial cells. Thorough examination of AhR expression in specific subpopulations of cells within the lung has not been reported. However, AhR is present in the lung, and TCDD directly impacts gene expression within lung cells, including airway epithelial cells, endothelial cells and Clara cells [37, 57, 93-95].

Thus, using influenza virus as a model of respiratory viral infection, these studies reveal that AhR activation affects immune function in a complex manner, in which innate and adaptive responses are modulated through distinct mechanisms. AhR-mediated increases in neutrophil recruitment and IFN- $\gamma$ production in the lung are caused by events extrinsic to bone marrow derived cells, with the likely targets being structural cells of the lung. In contrast, suppression of $\mathrm{CD}^{+} \mathrm{T}$ cell responses to infection occurs as a direct result of AhR activation within bone marrow derived cells. These findings are exciting, and reveal the existence of AhR-sensitive immunomodulatory pathways not only within bone marrow derived cells but in nonhematopoietic cells as well. Therefore, to fully understand how AhR modulates the function of the immune system, future studies need to consider how AhR impacts both hematopoietic and non-hematopoietic cells, and how changes in these distinct tissue compartments converge to impact host responses to infection.

\section{AhR-mediated effects on other aspects of viral infection}

Although exposure to TCDD reduces survival following infection with other viruses, specific effects of AhR activation on the immune response to other viruses have not been explicitly examined in vivo. However, given that TCDD and other AhR agonists have well documented immunomodulatory properties in a variety of in vivo systems [32], it is likely that AhR activation will result in similar alterations in innate and adaptive immune responses to other viruses. In addition to affecting immune responses to viral infection, there is evidence that $\mathrm{AhR}$ interacts with viral proteins and impacts viral latency. These effects, while only explored in a handful of studies, suggest that AhR may impact additional aspects of viral infection beyond influencing innate and adaptive responses. For example, it was recently reported that the Epstein-Barr virus (EBV)-encoded nuclear protein EBNA-3 interacts with the AhR and XAP-2 $[96,97]$. This is an intriguing discovery because EBNA-3 plays a role in the transformation of infected B cells [98], and although the underlying mechanism is not known, TCDD exposure is a risk factor in the development of non-Hodgkin lymphoma and other forms of cancer [99, 100]. EBNA-3 associates with AhR regardless of whether AhR has a ligand bound; however, in the presence of TCDD EBNA-3 enhances AhR-driven transcription [97]. The association of EBNA-3 with AhR may be via XAP2. XAP2 is believed to help retain the un-liganded AhR in the cytoplasm; however, in the presence of EBNA-3, XAP2 translocates to the nucleus. This suggests that EBNA-3 influences AhR-regulated genes by enhancing the transcriptionallyactive form of the AhR and helping to retain AhR in the nucleus. Whether AhR activation affects EBV-regulated cellular pathways or disrupts the immune response to acute EBV infection remains to be determined, but these studies suggest a merging or synergy between 
AhR- and EBV-regulated mechanisms that control cellular function. In addition to suggesting that AhR may interact with viral proteins in interesting ways, these observations may also partially explain the relationship between AhR activation and some forms of cancer.

Although only addressed in a small number of studies, there is also evidence that AhR activation triggers the replication of latent viruses. In several reports, treatment with different AhR agonists enhanced human immunodeficiency virus (HIV) gene expression and secreted p24 levels [101-104]. Using mutant AhR constructs and a dominant negative AhR, this effect on viral latency was shown to be AhR-dependent [103]. Evidence for cross-talk between AhR with NF- $\kappa B$ has been provided by some of these studies [101,102], but not in others [103], which leaves the mechanism by which AhR influences HIV latency uncertain. In a separate model system, AhR activation increased replication of latent CMV and enhanced CMV-related cytopathic effects [105]. Whether AhR ligands influence the replication of latent viruses in vivo has not been reported, but given keen interest in understanding mechanisms that control viral latency these reports highlight the need advance this line of inquiry.

\section{Conclusions}

There is still much to learn about how AhR influences host responses to viral infection. There are clearly multiple molecular targets that underlie AhR-mediated regulation of innate and adaptive immune responses. The increased recruitment of neutrophils, production of IFN- $\gamma$ and iNOS expression associated with AhR activation are caused by events extrinsic to hematopoietic cells, and suggest that AhR affects signaling within endothelial and epithelial cells. However, AhR-mediated suppression of virus specific $\mathrm{CD} 8^{+} \mathrm{T}$ cells is deregulated by mechanisms that involve direct events within bone marrow derived cells. Furthermore, AhR activation appears to target mechanisms that regulate other aspects of host cell-virus interactions, although these have received less attention. Among the many aspects that remain to be determined are the precise cellular targets, pathways, and mechanisms by which AhRactivation causes these effects.

Given that the AhR is a ligand-activated transcription factor, it has become widely accepted that all actions of the AhR result from changes in gene expression [35,106,107]. Much effort to understand transcriptional regulation by AhR has focused on a mechanism that involves nuclear translocation of ligand bound AhR, association with Arnt (HIF-1 $\beta$ ) and binding to AhRE [35,107]. In addition to this canonical pathway of AhR-mediated transcriptional regulation, alternative pathways for AhR-mediated changes in cellular function have recently been proposed in which ligand-bound AhR interacts with other signaling pathways. Proposed alternative mechanisms include the interaction of $\mathrm{AhR}$ with proteins that affect cellular function, such as NF- $\mathrm{kB}$, immunophilins, CCAAT-enhancer box binding protein beta (C/EBP$\beta$ ), estrogen receptor (ER) $\alpha$, and retinoblastoma protein [83,108-113]. Thus, it is possible that AhR participates in multiple pathways during the immune response to viral infection, and the precise pathway affected depends on multiple parameters including virus type and the site of infection.

Although AhR likely impacts anti-viral immune responses via changes in transcriptional activation, the affected genes have yet to be identified. In other experimental systems, AhR activation alters the expression of several immunoregulatory genes, and putative AhRE have been identified in the enhancer/promoter regions of a handful of cytokine genes [114-117]. However, a cause-and-effect relationship between possible AhR-mediated changes in gene expression and immune function has yet to be made. Moreover, AhR-mediated changes in gene expression in virally-infected cells and tissues have not been examined. Given that viruses commonly impact gene expression by host cells, the interplay between AhR and viral mechanisms could present a complex profile of affected genes. Thus, it will be critical to 
experimentally distinguish direct targets of AhR activation from bystanders and down-stream effects of virus-mediated modulation of the host response. Furthermore, most of what we know about AhR-mediated deregulation of anti-viral immune responses has been examined in the context of respiratory infection with influenza A virus. Consequently, there are significant gaps in our knowledge regarding how AhR activation impacts host-virus interactions and immune responses to infection at other anatomical sites. Future work should therefore address these understudied areas and determine the consequences of AhR activation during the immune response to other viruses and at other anatomical sites.

Given that immune suppression by exposure to AhR ligands, such as TCDD, has been known for a long time, suppression of adaptive responses to infection with influenza virus is not surprising, as it is the expected outcome. However, the idea that AhR activation enhances aspects of the host's response to infection, and does so via affecting targets extrinsic to the immune system, presents a newer and broader idea of AhR as a modulator of immune function. For example, the ability of to AhR influence the influx of neutrophils into the lung by targeting signaling pathways within the lung is a novel idea, with broad implications for health.

Neutrophils aid in the resolution of infection, yet excessive recruitment generally has adverse effects. The mechanisms that control excessive neutrophil recruitment during viral infection remain poorly characterized. Discovering how AhR affects epithelial and endothelial cells to modulate neutrophil recruitment will reveal critical targets that control the balance point between too much and not enough inflammation during viral infection.

In addition to understanding how pollutants deregulate anti-viral immunity and contribute to poorer clinical outcomes, mechanistic understanding of how AhR agonists modify host responses involved in combating viral infection is important because it will provide new information regarding specific aspects of the disease process that are susceptible to modulation. In fact, identification of molecular targets of environmental toxins, such as TCDD, has already revealed novel pathways for potential new drugs and therapeutic strategies to modify host responses to antigen challenge $[84,88,89]$. Current challenges are to move beyond the study of TCDD as a pollutant and understand the biology of AhR as a regulator of host responses to viral infection. Indeed, given that many of the same immunoregulatory pathways are activated in response to other types of antigens, it is quite likely that delineating the mechanisms of AhRmediated immune modulation in the context of responses to viruses will stimulate new therapies to aid in the treatment of other diseases.

\section{Acknowledgements}

On-going research in our laboratory is supported by the following research and training grants from the National Institutes of Health: K02-ES012409 (B.P.L), R01-ES013958 (B.P.L) and R21-ES013863 (B.P.L), T32-ES07026 (J.L.H.), and P30-ES01247.

\section{Abbreviations}

AhR

aryl hydrocarbon receptor

$\mathbf{A h R}^{+/+}$

AhR wild-type

$\mathbf{A h R}^{-1-}$

AhR deficient

AhRE

AhR response element 
Arnt

$\begin{array}{ll} & \text { AhR nuclear translocator } \\ \text { C/EBP- } \boldsymbol{\beta} & \\ \text { CMV } & \text { CCAAT-enhancer box binding protein beta } \\ \text { CTL } & \text { Cytomegalovirus } \\ & \text { Cytotoxic T lymphocytes } \\ \text { DC } & \\ & \text { Dendritic cell }\end{array}$

\section{EBNA-3}

EBV nuclear antigen

EBV

Epstein-Barr virus

ER-a

Estrogen receptor alpha

HIF-1及

Hypoxia inducible factor-1 beta

HIV

Human immunodeficiency virus

HSV-1

Herpes simplex virus-1

IFN- $\gamma$

Interferon gamma

iNOS

inducible nitric oxide synthase

MHC

major histocompatability complex

NF-אB

Nuclear factor kappa B

NK cell

Natural killer cell

NO

Nitric oxide

PRR

Pattern recognition receptor

RSV

Respiratory syncytial virus

TCDD

2,3,7,8-tetrachlorodibenzo- $p$-dioxin

Biochem Pharmacol. Author manuscript; available in PMC 2010 February 15. 
Th17

$$
\text { IL-17 producing T helper cells }
$$

$\mathbf{T}_{\text {reg }}$

$$
\mathrm{CD} 4{ }^{+} \mathrm{CD} 25^{+} \text {regulatory } \mathrm{T} \text { cells }
$$

XAP-2

$$
\mathrm{X} \text {-associated protein } 2
$$

\section{References}

1. World Health Organization. Acute Respiratory Infections. 2005. www.who.int/vaccine_research/diseases/ari/en

2. Anderson R, Smith B. Deaths: leading causes for 2002. Natl Vital Stat Rep 2005;53:1-89. [PubMed: 15786629]

3. Hill AV. The immunogenetics of human infectious diseases. Annu Rev Immunol 1998;16:593-617. [PubMed: 9597143]

4. Colosio C, Birindelli S, Corsini E, Galli CL, Maroni M. Low level exposure to chemicals and immune system. Toxicol Appl Pharmacol 2005;207:320-8. [PubMed: 15992843]

5. Frampton MW, Samet JM, Utell MJ. Environmental factors and atmospheric pollutants. Semin Respir Infect 1991;6:185-93. [PubMed: 1809997]

6. Singh V. The burden of pneumonia in children: an Asian perspective. Paediatr Respir Rev 2005;6:8893. [PubMed: 15911453]

7. Spannhake EW, Reddy SP, Jacoby DB, Yu XY, Saatian B, Tian J. Synergism between rhinovirus infection and oxidant pollutant exposure enhances airway epithelial cell cytokine production. Environ Health Perspect 2002;110:665-70. [PubMed: 12117643]

8. Van Den Heuvel RL, Koppen G, Staessen JA, Hond ED, Verheyen G, Nawrot TS, et al. Immunologic biomarkers in relation to exposure markers of PCBs and dioxins in Flemish adolescents (Belgium). Environ Health Perspect 2002;110:595-600. [PubMed: 12055051]

9. Jung D, Berg PA, Edler L, Ehrenthal W, Fenner D, Flesch-Janys D, et al. Immunologic findings in workers formerly exposed to 2,3,7,8-tetrachlorodibenzo-p-dioxin and its congeners. Environ Health Perspect 1998;106(Suppl 2):689-95. [PubMed: 9599718]

10. Tonn T, Esser C, Schneider EM, Steinmann-Steiner-Haldenstatt W, Gleichmann E. Persistence of decreased T-helper cell function in industrial workers 20 years after exposure to 2,3,7,8tetrachlorodibenzo-p-dioxin. Environ Health Perspect 1996;104:422-6. [PubMed: 8732953]

11. Weisglas-Kuperus N, Patandin S, Berbers GA, Sas TC, Mulder PG, Sauer PJ, et al. Immunologic effects of background exposure to polychlorinated biphenyls and dioxins in Dutch preschool children. Environ Health Perspect 2000;108:1203-7. [PubMed: 11133402]

12. Sopori, M.; Goud, N.; Kaplan, A. Effects of tobacco smoke on the immune systems. In: Dean, J.; Luster, M.; Munson, AIK., editors. Immunotoxicology and Immunopharmacology. New York: Raven Press; 1994. p. 413-34.

13. Clark DA, Sweeney G, Safe S, Hancock E, Kilburn DG, Gauldie J. Cellular and genetic basis for suppression of cytotoxic $\mathrm{T}$ cell generation by haloaromatic hydrocarbons. Immunopharmacology 1983;6:143-53. [PubMed: 6309701]

14. Funseth E, Wesslen L, Lindh U, Friman G, Ilback NG. Effect of 2,3,7,8-tetrachlorodibenzo-p-dioxin on trace elements, inflammation and viral clearance in the myocardium during coxsackievirus B3 infection in mice. Sci Total Environ 2002;284:135-47. [PubMed: 11846158]

15. Vorderstrasse BA, Bohn AA, Lawrence BP. Examining the relationship between impaired host resistance and altered immune function in mice treated with TCDD. Toxicology 2003;188:15-28. [PubMed: 12748038]

16. Warren TK, Mitchell KA, Lawrence BP. Exposure to 2,3,7,8-tetrachlorodibenzo-p-dioxin (TCDD) suppresses the humoral and cell-mediated immune responses to influenza A virus without affecting cytolytic activity in the lung. Toxicol Sci 2000;56:114-23. [PubMed: 10869459] 
17. Burleson GR, Lebrec H, Yang YG, Ibanes JD, Pennington KN, Birnbaum LS. Effect of 2,3,7,8tetrachlorodibenzo-p-dioxin (TCDD) on influenza virus host resistance in mice. Fundam Appl Toxicol 1996;29:40-7. [PubMed: 8838638]

18. Luebke RW, Copeland CB, Bishop LR, Daniels MJ, Gilmour MI. Mortality in dioxin-exposed mice infected with influenza: mitochondrial toxicity (reye's-like syndrome) versus enhanced inflammation as the mode of action. Toxicol Sci 2002;69:109-16. [PubMed: 12215664]

19. Nohara K, Izumi H, Tamura S, Nagata R, Tohyama C. Effect of low-dose 2,3,7,8-tetrachlorodibenzop-dioxin (TCDD) on influenza A virus-induced mortality in mice. Toxicology 2002;170:131-8. [PubMed: 11750090]

20. Dempsey PW, Vaidya SA, Cheng G. The art of war: Innate and adaptive immune responses. Cell Mol Life Sci 2003;60:2604-21. [PubMed: 14685686]

21. Bender A, Albert M, Reddy A, Feldman M, Sauter B, Kaplan G, et al. The distinctive features of influenza virus infection of dendritic cells. Immunobiology 1998;198:552-67. [PubMed: 9561373]

22. Brimnes MK, Bonifaz L, Steinman RM, Moran TM. Influenza virus-induced dendritic cell maturation is associated with the induction of strong $\mathrm{T}$ cell immunity to a coadministered, normally nonimmunogenic protein. J Exp Med 2003;198:133-44. [PubMed: 12847140]

23. Legge KL, Braciale TJ. Accelerated migration of respiratory dendritic cells to the regional lymph nodes is limited to the early phase of pulmonary infection. Immunity 2003;18:265-77. [PubMed: 12594953]

24. Wareing MD, Lyon AB, Lu B, Gerard C, Sarawar SR. Chemokine expression during the development and resolution of a pulmonary leukocyte response to influenza A virus infection in mice. J Leukoc Biol 2004;76:886-95. [PubMed: 15240757]

25. Woodland DL, Hogan RJ, Zhong W. Cellular immunity and memory to respiratory virus infections. Immunol Res 2001;24:53-67. [PubMed: 11485209]

26. Lawrence BP, Roberts AD, Neumiller JJ, Cundiff JA, Woodland DL. Aryl hydrocarbon receptor activation impairs the priming but not the recall of influenza virus-specific CD8+ T cells in the lung. J Immunol 2005;177:5819-28. [PubMed: 17056506]

27. Gerhard W, Mozdzanowska K, Furchner M, Washko G, Maiese K. Role of the B-cell response in recovery of mice from primary influenza virus infection. Immunol Rev 1997;159:95-103. [PubMed: 9416505]

28. Janssen EM, Lemmens EE, Wolfe T, Christen U, von Herrath MG, Schoenberger SP. CD4+ T cells are required for secondary expansion and memory in CD8+ T lymphocytes. Nature 2003;421:8526. [PubMed: 12594515]

29. Hikono H, Kohlmeier JE, Ely KH, Scott I, Roberts AD, Blackman MA, et al. T-cell memory and recall responses to respiratory virus infections. Immunol Rev 2006;211:119-32. [PubMed: 16824122]

30. Doherty PC, Topham DJ, Tripp RA, Cardin RD, Brooks JW, Stevenson PG. Effector CD4+ and CD8 + T-cell mechanisms in the control of respiratory virus infections. Immunol Rev 1997;159:105-17. [PubMed: 9416506]

31. Kerkvliet NI. Recent advances in understanding the mechanisms of TCDD immunotoxicity. Int Immunopharmacol 2002;2:277-91. [PubMed: 11811931]

32. Lawrence, BP.; Kerkvliet, NI. Imune Modulation by TCDD and Related Polyhalogenated Aromatic Hydrocarbons. In: Luebke, R.; House, R.; Kimber, I., editors. Immunotoxicology and Immunopharmacology. CRC Press; 2006. p. 239-58.

33. Teske S, Bohn AA, Regal JF, Neumiller JJ, Lawrence BP. Exploring mechanisms that underlie aryl hydrocarbon receptor-mediated increases in pulmonary neutrophilia and diminished host resistance to influenza A virus. Am J Physiol Lung Cell Mol Physiol 2005;289:111-24.

34. Vorderstrasse BA, Steppan LB, Silverstone AE, Kerkvliet NI. Aryl hydrocarbon receptor-deficient mice generate normal immune responses to model antigens and are resistant to TCDD-induced immune suppression. Toxicol Appl Pharmacol 2001;171:157-64. [PubMed: 11243915]

35. Nguyen L, Bradfield C. The search for endogenous activators of the aryl hydrocarbon receptor. Chem Res Toxicol 2008;21:102-16. [PubMed: 18076143] 
36. White, K.; Kawabata, T.; Ladics, G. Mechanisms of polycyclic aromatic hydrocarbon immunotoxicity. In: Dean, J.; Luster, M.; Munson, A.; Kimber, I., editors. Immunotoxicology and Immunopharmacology. New York: Raven Press; 2005. p. 123-42.

37. Martey CA, Baglole CJ, Gasiewicz TA, Sime PJ, Phipps RP. The aryl hydrocarbon receptor is a regulator of cigarette smoke induction of the cyclooxygenase and prostaglandin pathways in human lung fibroblasts. Am J Physiol Lung Cell Mol Physiol 2005;289:L391-9. [PubMed: 15863442]

38. Rodriguez-Sosa M, Elizondo G, Lopez-Duran RM, Rivera I, Gonzalez FJ, Vega L. Overproduction of IFN-gamma and IL-12 in AhR-null mice. FEBS Lett 2005;579:6403-10. [PubMed: 16289099]

39. Thurmond TS, Staples JE, Silverstone AE, Gasiewicz TA. The aryl hydrocarbon receptor has a role in the in vivo maturation of murine bone marrow B lymphocytes and their response to 2,3,7,8tetrachlorodibenzo-p-dioxin. Toxicol Appl Pharmacol 2000;165:227-36. [PubMed: 10860871]

40. House RV, Lauer LD, Murray MJ, Thomas PT, Ehrlich JP, Burleson GR, et al. Examination of immune parameters and host resistance mechanisms in $\mathrm{B} 6 \mathrm{C} 3 \mathrm{~F} 1$ mice following adult exposure to 2,3,7,8-tetrachlorodibenzo-p-dioxin. J Toxicol Environ Health 1990;31:203-15. [PubMed: 1700136]

41. Lawrence BP, Warren TK, Luong H. Fewer T lymphocytes and decreased pulmonary influenza virus burden in mice exposed to 2,3,7,8-tetrachlorodibenzo-p-dioxin (TCDD). J Toxicol Environ Health A 2000;61:39-53. [PubMed: 10990162]

42. Neff-LaFord HD, Vorderstrasse BA, Lawrence BP. Fewer CTL, not enhanced NK cells, are sufficient for viral clearance from the lungs of immunocompromised mice. Cell Immunol 2003;226:54-64. [PubMed: 14746808]

43. Tate MD, Brooks AG, Reading PC. The role of neutrophils in the upper and lower respiratory tract during influenza virus infection of mice. Respir Res 2008;9:57. [PubMed: 18671884]

44. Fujisawa H. Neutrophils Play an Essential Role in Cooperation with Antibody in both Protection against and Recovery from Pulmonary Infection with Influenza Virus in Mice. J Virol 2008;82:277283. [PubMed: 18184718]

45. Smith P, Wang S, Dowling K, Forsyth K. Leucocyte populations in respiratory syncytial virus-induced bronchiolitis. J Paediatr Child Health 2001;37:146-51. [PubMed: 11328469]

46. Tumpey TM, Garcia-Sastre A, Taubenberger JK, Palese P, Swayne DE, Pantin-Jackwood MJ, et al. Pathogenicity of Influenza Viruses with Genes from the 1918 Pandemic Virus: Functional Roles of Alveolar Macrophages and Neutrophils in Limiting Virus Replication and Mortality in Mice. J Virol 2005;79:14933-44. [PubMed: 16282492]

47. Everard ML, Swarbrick A, Wrightham M, McIntyre J, Dunkley C, James PD, et al. Analysis of cells obtained by bronchial lavage of infants with respiratory syncytial virus infection. Archives of Disease in Childhood 1994;71:428-32. [PubMed: 7826113]

48. Yan X-T, Tumpey TM, Kunkel SL, Oakes JE, Lausch RN. Role of MIP-2 in Neutrophil Migration and Tissue Injury in Herpes Simplex Virus-1 Infected Cornea. Invest O[hthalmol Vis Sci 1998;39:1854-62.

49. Craigen JL, Yong KL, Jordan NJ, Maccormac LP, Westwick J, Akbar AN, et al. Human cytomegalovirus infection up-regulates interleukin- 8 gene expression and stimulates neutrophil transendothelial migration. Immunology 1997;92:138-45. [PubMed: 9370936]

50. Gualano RC, Hansen MJ, Vlahos R, Jones JE, Park-Jones RA, Deliyannis G, et al. Cigarette smoke worsens lung inflammation and impairs resolution of influenza infection in mice. Respir Res 2008;9:53. [PubMed: 18627612]

51. Choi JY, Oughton JA, Kerkvliet NI. Functional alterations in CD11b(+)Gr-1(+) cells in mice injected with allogeneic tumor cells and treated with 2,3,7,8-tetrachlorodibenzo-p-dioxin. Int Immunopharmacol 2003;3:553-70. [PubMed: 12689660]

52. Fan F, Yan B, Wood G, Viluksela M, Rozman KK. Cytokines (IL-1beta and TNFalpha) in relation to biochemical and immunological effects of 2,3,7,8-tetrachlorodibenzo-p-dioxin (TCDD) in rats. Toxicology 1997;116:9-16. [PubMed: 9020502]

53. Moos AB, Oughton JA, Kerkvliet NI. The effects of 2,3,7,8-tetrachlorodibenzo-p-dioxin (TCDD) on tumor necrosis factor (TNF) production by peritoneal cells. Toxicol Lett 1997;90:145-53. [PubMed: 9067482] 
54. Vorderstrasse BA, Lawrence BP. Protection against lethal challenge with Streptococcus pneumoniae is conferred by aryl hydrocarbon receptor activation but is not associated with an enhanced inflammatory response. Infect Immun 2006;74:5679-86. [PubMed: 16988243]

55. Kanneganti TD, Lamkanfi M, Nunez G. Intracellular NOD-like receptors in host defense and disease. Immunity 2007;27:549-59. [PubMed: 17967410]

56. Teske S, Bohn AA, Hogaboam JP, Lawrence BP. Aryl hydrocarbon receptor targets pathways extrinsic to bone marrow cells to enhance neutrophil recruitment during influenza virus infection. Toxicol Sci 2008;102:89-99. [PubMed: 18007012]

57. Bohn AA, Harrod KS, Teske S, Lawrence BP. Increased mortality associated with TCDD exposure in mice infected with influenza A virus is not due to severity of lung injury or alterations in Clara cell protein content. Chem Biol Interact 2005;155:181-90. [PubMed: 16040023]

58. Neff-LaFord H, Teske S, Bushnell TP, Lawrence BP. Aryl hydrocarbon receptor activation during influenza virus infection unveils a novel pathway of IFN-gamma production by phagocytic cells. J Immunol 2007;179:247-55. [PubMed: 17579044]

59. Akaike T, Maeda H. Nitric oxide and virus infection. Immunology 2000;101:300-8. [PubMed: 11106932]

60. Karupiah G, Chen JH, Mahalingam S, Nathan CF, MacMicking JD. Rapid interferon gammadependent clearance of influenza A virus and protection from consolidating pneumonitis in nitric oxide synthase 2-deficient mice. J Exp Med 1998;188:1541-6. [PubMed: 9782132]

61. Stark JM, Khan AM, Chiappetta CL, Xue H, Alcorn JL, Colasurdo GN. Immune and Functional Role of Nitric Oxide in a Mouse Model of Respiratory Syncytial Virus Infection. Journal of Infectious Diseases 2005;191:387-95. [PubMed: 15633098]

62. Fujii S, Akaike T, Maeda H. Role of Nitric Oxide in Pathogenesis of Herpes Simplex Virus Encephalitis in Rats. Virology 1999;256:203-12. [PubMed: 10191185]

63. Kleinert H, Pautz A, Linker K, Schwarz PM. Regulation of the expression of inducible nitric oxide synthase. Eur J Pharmacol 2004;500:255-66. [PubMed: 15464038]

64. Mitchell KA, Lawrence BP. Exposure to 2,3,7,8-tetrachlorodibenzo-p-dioxin (TCDD) renders influenza virus-specific CD8+ T cells hyporesponsive to antigen. Toxicol Sci 2003;74:74-84. [PubMed: 12730613]

65. Mitchell KA, Lawrence BP. T cell receptor transgenic mice provide novel insights into understanding cellular targets of TCDD: suppression of antibody production, but not the response of CD8(+) T cells, during infection with influenza virus. Toxicol Appl Pharmacol 2003;192:275-86. [PubMed: 14575645]

66. Maletic N, Graham B. Cytokne release and innate immunity in respiratory viral infection. Semin Virol 1996;7:255-64.

67. Guidotti LG, Chisari FV. Noncytolytic control of viral infections by the innate and adaptive immune response. Annu Rev Immunol 2001;19:65-91. [PubMed: 11244031]

68. Allan W, Tabi Z, Cleary A, Doherty PC. Cellular events in the lymph node and lung of mice with influenza. Consequences of depleting CD4+ T cells. J Immunol 1990;144:3980-6. [PubMed: 1692070]

69. Chen W, Bennink JR, Morton PA, Yewdell JW. Mice deficient in perforin, CD4+ T cells, or CD28mediated signaling maintain the typical immunodominance hierarchies of CD8+ T-cell responses to influenza virus. J Virol 2002;76:10332-7. [PubMed: 12239309]

70. Belz GT, Wodarz D, Diaz G, Nowak MA, Doherty PC. Compromised influenza virus-specific CD8 (+)-T-cell memory in CD4(+)-T-cell-deficient mice. J Virol 2002;76:12388-93. [PubMed: 12414983]

71. Lawrence BP, Vorderstrasse BA. Activation of the aryl hydrocarbon receptor diminishes the memory response to homotypic influenza virus infection but does not impair host resistance. Toxicol Sci 2004;79:304-14. [PubMed: 14976337]

72. Kerkvliet NI, Brauner JA. Mechanisms of 1,2,3,4,6,7,8-heptachlorodibenzo-p-dioxin (HpCDD)induced humoral immune suppression: evidence of primary defect in T-cell regulation. Toxicol Appl Pharmacol 1987;87:18-31. [PubMed: 3492063] 
73. Sulentic CE, Holsapple MP, Kaminski NE. Aryl hydrocarbon receptor-dependent suppression by 2,3,7, 8-tetrachlorodibenzo-p-dioxin of IgM secretion in activated B cells. Mol Pharmacol 1998;53:623-9. [PubMed: 9547351]

74. Wood SC, Holsapple MP. Direct suppression of superantigen-induced IgM secretion in human lymphocytes by 2,3,7,8-TCDD. Toxicol Appl Pharmacol 1993;122:308-13. [PubMed: 8212013]

75. Shepherd DM, Dearstyne EA, Kerkvliet NI. The effects of TCDD on the activation of ovalbumin (OVA)-specific DO11.10 transgenic CD4(+) T cells in adoptively transferred mice. Toxicol Sci 2000;56:340-50. [PubMed: 10910992]

76. Moran RA, Lee CW, Fujimoto JM, Calvanico NJ. Effects of 2,3,7,8-tetrachlorodibenzo-p-dioxin (TCDD) on IgA serum and bile levels in rats. Immunopharmacology 1986;12:245-50. [PubMed: 3818260]

77. Tecle T, White MR, Gantz D, Crouch EC, Hartshorn KL. Human neutrophil defensins increase neutrophil uptake of influenza A virus and bacteria and modify virus-induced respiratory burst responses. J Immunol 2007;178:8046-52. [PubMed: 17548642]

78. Ueno H, Klechevsky E, Morita R, Aspord C, Cao T, Matsui T, et al. Dendritic cell subsets in health and disease. Immunol Rev 2007;219:118-42. [PubMed: 17850486]

79. Vorderstrasse BA, Dearstyne EA, Kerkvliet NI. Influence of 2,3,7,8-tetrachlorodibenzo-p-dioxin on the antigen-presenting activity of dendritic cells. Toxicol Sci 2003;72:103-12. [PubMed: 12604839]

80. Vorderstrasse BA, Kerkvliet NI. 2,3,7,8-Tetrachlorodibenzo-p-dioxin affects the number and function of murine splenic dendritic cells and their expression of accessory molecules. Toxicol Appl Pharmacol 2001;171:117-25. [PubMed: 11222087]

81. Laupeze B, Amiot L, Sparfel L, Le Ferrec E, Fauchet R, Fardel O. Polycyclic aromatic hydrocarbons affect functional differentiation and maturation of human monocyte-derived dendritic cells. $\mathrm{J}$ Immunol 2002;168:2652-8. [PubMed: 11884429]

82. Ruby CE, Funatake CJ, Kerkvliet NI. 2,3,7,8 Tetrachlorodibenzo- -Dioxin (TCDD) Directly Enhances the Maturation and Apoptosis of Dendritic Cells In Vitro. J Immunotox 2004;1:159-66.

83. Ruby CE, Leid M, Kerkvliet NI. 2,3,7,8-Tetrachlorodibenzo-p-dioxin suppresses tumor necrosis factor-alpha and anti-CD40-induced activation of NF-kappaB/Rel in dendritic cells: p50 homodimer activation is not affected. Mol Pharmacol 2002;62:722-8. [PubMed: 12181450]

84. Lawrence BP, Denison MS, Novak H, Vorderstrasse BA, Harrer N, Neruda W, et al. Activation of the aryl hydrocarbon receptor is essential for mediating the anti-inflammatory effects of a novel low molecular weight compound. Blood. 2008

85. Lee JA, Hwang JA, Sung HN, Jeon CH, Gill BC, Youn HJ, et al. 2,3,7,8-Tetrachlorodibenzo-p-dioxin modulates functional differentiation of mouse bone marrow-derived dendritic cells Downregulation of RelB by 2,3,7,8-tetrachlorodibenzo-p-dioxin. Toxicol Lett 2007;173:31-40. [PubMed: 17681673]

86. Funatake CJ, Marshall NB, Steppan LB, Mourich DV, Kerkvliet NI. Cutting edge: activation of the aryl hydrocarbon receptor by 2,3,7,8-tetrachlorodibenzo-p-dioxin generates a population of CD4+ CD25+ cells with characteristics of regulatory T cells. J Immunol 2005;175:4184-8. [PubMed: 16177056]

87. Kimura A, Naka T, Nohara K, Fujii-Kuriyama Y, Kishimoto T. Aryl hydrocarbon receptor regulates Stat 1 activation and participates in the development of Th17 cells. Proc Natl Acad Sci U S A 2008;105:9721-6. [PubMed: 18607004]

88. Veldhoen M, Hirota K, Westendorf AM, Buer J, Dumoutier L, Renauld JC, et al. The aryl hydrocarbon receptor links TH17-cell-mediated autoimmunity to environmental toxins. Nature 2008;453:106-9. [PubMed: 18362914]

89. Quintana FJ, Basso AS, Iglesias AH, Korn T, Farez MF, Bettelli E, et al. Control of T(reg) and T(H) 17 cell differentiation by the aryl hydrocarbon receptor. Nature 2008;453:65-71. [PubMed: 18362915]

90. Haeryfar SM, DiPaolo RJ, Tscharke DC, Bennink JR, Yewdell JW. Regulatory T cells suppress CD8 $+\mathrm{T}$ cell responses induced by direct priming and cross-priming and moderate immunodominance disparities. J Immunol 2005;174:3344-51. [PubMed: 15749866]

91. Belkaid Y, Rouse BT. Natural regulatory T cells in infectious disease. Nat Immunol 2005;6:353-60. [PubMed: 15785761]

92. Zhou Y. Regulatory T cells and viral infections. Front Biosci 2008;13:1152-70. [PubMed: 17981620] 
93. Zhang N, Walker MK. Crosstalk between the aryl hydrocarbon receptor and hypoxia on the constitutive expression of cytochrome P4501A1 mRNA. Cardiovasc Toxicol 2007;7:282-90. [PubMed: 17968679]

94. Chang H, Chang LW, Cheng YH, Tsai WT, Tsai MX, Lin P. Preferential induction of CYP1A1 and CYP1B1 in CCSP-positive cells. Toxicol Sci 2006;89:205-13. [PubMed: 16237193]

95. Lang DS, Becker S, Devlin RB, Koren HS. Cell-specific differences in the susceptibility of potential cellular targets of human origin derived from blood and lung following treatment with 2,3,7,8tetrachlorodibenzo-p-dioxin (TCDD). Cell Biol Toxicol 1998;14:23-38. [PubMed: 9538942]

96. Kashuba E, Kashuba V, Pokrovskaja K, Klein G, Szekely L. Epstein-Barr virus encoded nuclear protein EBNA-3 binds XAP-2, a protein associated with Hepatitis B virus X antigen. Oncogene 2000;19:1801-6. [PubMed: 10777214]

97. Kashuba EV, Gradin K, Isaguliants M, Szekely L, Poellinger L, Klein G, et al. Regulation of transactivation function of the aryl hydrocarbon receptor by the Epstein-Barr virus-encoded EBNA-3 protein. J Biol Chem 2006;281:1215-23. [PubMed: 16257957]

98. Kuppers R. B cells under influence: transformation of B cells by Epstein-Barr virus. Nat Rev Immunol 2003;3:801-12. [PubMed: 14523386]

99. Hardell L, Lindstrom G, van Bavel B, Hardell K, Linde A, Carlberg M, et al. Adipose tissue concentrations of dioxins and dibenzofurans, titers of antibodies to Epstein-Barr virus early antigen and the risk for non-Hodgkin lymphoma. Environ Res 2001;87:99-107. [PubMed: 11683593]

100. Stancek D, Kosecka G, Oltman M, Keleova A, Jahnova E. Links between prolonged exposure to xenobiotics, increased incidence of hepatopathies, immunological disturbances and exacerbation of latent Epstein-Barr virus infections. Int J Immunopharmacol 1995;17:321-8. [PubMed: 7672882]

101. Yao Y, Hoffer A, Chang CY, Puga A. Dioxin activates HIV-1 gene expression by an oxidative stress pathway requiring a functional cytochrome P450 CYP1A1 enzyme. Environ Health Perspect 1995;103:366-71. [PubMed: 7607137]

102. Gollapudi S, Kim CH, Patel A, Sindhu R, Gupta S. Dioxin activates human immunodeficiency virus-1 expression in chronically infected promonocytic U1 cells by enhancing NF-kappa B activity and production of tumor necrosis factor-alpha. Biochem Biophys Res Commun 1996;226:889-94. [PubMed: 8831706]

103. Ohata H, Tetsuka T, Hayashi H, Onozaki K, Okamoto T. 3-methylcholanthrene activates human immunodeficiency virus type 1 replication via aryl hydrocarbon receptor. Microbiol Immunol 2003;47:363-70. [PubMed: 12825898]

104. Tsyrlov IB, Pokrovsky A. Stimulatory effect of the CYP1A1 inducer 2,3,7,8-tetrachlorodibenzo-pdioxin on the reproduction of HIV-1 in human lymphoid cell culture. Xenobiotica 1993;23:45767. [PubMed: 7687806]

105. Murayama T, Inoue M, Nomura T, Mori S, Eizuru Y. 2,3,7,8-Tetrachlorodibenzo-p-dioxin is a possible activator of human cytomegalovirus replication in a human fibroblast cell line. Biochem Biophys Res Commun 2002;296:651-6. [PubMed: 12176031]

106. Denison MS, Nagy SR. Activation of the aryl hydrocarbon receptor by structurally diverse exogenous and endogenous chemicals. Annu Rev Pharmacol Toxicol 2003;43:309-34. [PubMed: 12540743]

107. Fujii-Kuriyama Y, Mimura J. Molecular mechanisms of AhR functions in the regulation of cytochrome P450 genes. Biochem Biophys Res Commun 2005;338:311-7. [PubMed: 16153594]

108. Carver LA, Bradfield CA. Ligand-dependent interaction of the aryl hydrocarbon receptor with a novel immunophilin homolog in vivo. J Biol Chem 1997;272:11452-6. [PubMed: 9111057]

109. Kim DW, Gazourian L, Quadri SA, Romieu-Mourez R, Sherr DH, Sonenshein GE. The RelA NFkappaB subunit and the aryl hydrocarbon receptor $(\mathrm{AhR})$ cooperate to transactivate the c-myc promoter in mammary cells. Oncogene 2000;19:5498-506. [PubMed: 11114727]

110. Meyer BK, Pray-Grant MG, Vanden Heuvel JP, Perdew GH. Hepatitis B virus X-associated protein 2 is a subunit of the unliganded aryl hydrocarbon receptor core complex and exhibits transcriptional enhancer activity. Mol Cell Biol 1998;18:978-88. [PubMed: 9447995]

111. Tian Y, Ke S, Denison MS, Rabson AB, Gallo MA. Ah receptor and NF-kappaB interactions, a potential mechanism for dioxin toxicity. J Biol Chem 1999;274:510-5. [PubMed: 9867872] 
112. Puga A, Barnes SJ, Chang C, Zhu H, Nephew KP, Khan SA, et al. Activation of transcription factors activator protein-1 and nuclear factor-kappaB by 2,3,7,8-tetrachlorodibenzo-p-dioxin. Biochem Pharmacol 2000;59:997-1005. [PubMed: 10692565]

113. Puga A, Barnes SJ, Dalton TP, Chang C, Knudsen ES, Maier MA. Aromatic hydrocarbon receptor interaction with the retinoblastoma protein potentiates repression of E2F-dependent transcription and cell cycle arrest. J Biol Chem 2000;275:2943-50. [PubMed: 10644764]

114. Lai ZW, Pineau T, Esser C. Identification of dioxin-responsive elements (DREs) in the 5' regions of putative dioxin-inducible genes. Chem Biol Interact 1996;100:97-112. [PubMed: 8646792]

115. Zeytun A, McKallip RJ, Fisher M, Camacho I, Nagarkatti M, Nagarkatti PS. Analysis of 2,3,7,8tetrachlorodibenzo-p-dioxin-induced gene expression profile in vivo using pathway-specific cDNA arrays. Toxicology 2002;178:241-60. [PubMed: 12167310]

116. Boverhof DR, Tam E, Harney AS, Crawford RB, Kaminski NE, Zacharewski TR. 2,3,7,8Tetrachlorodibenzo-p-dioxin induces suppressor of cytokine signaling 2 in murine B cells. Mol Pharmacol 2004;66:1662-70. [PubMed: 15371557]

117. Nagai H, Takei T, Tohyama C, Kubo M, Abe R, Nohara K. Search for the target genes involved in the suppression of antibody production by TCDD in C57BL/6 mice. Int Immunopharmacol 2005;5:331-43. [PubMed: 15652763] 


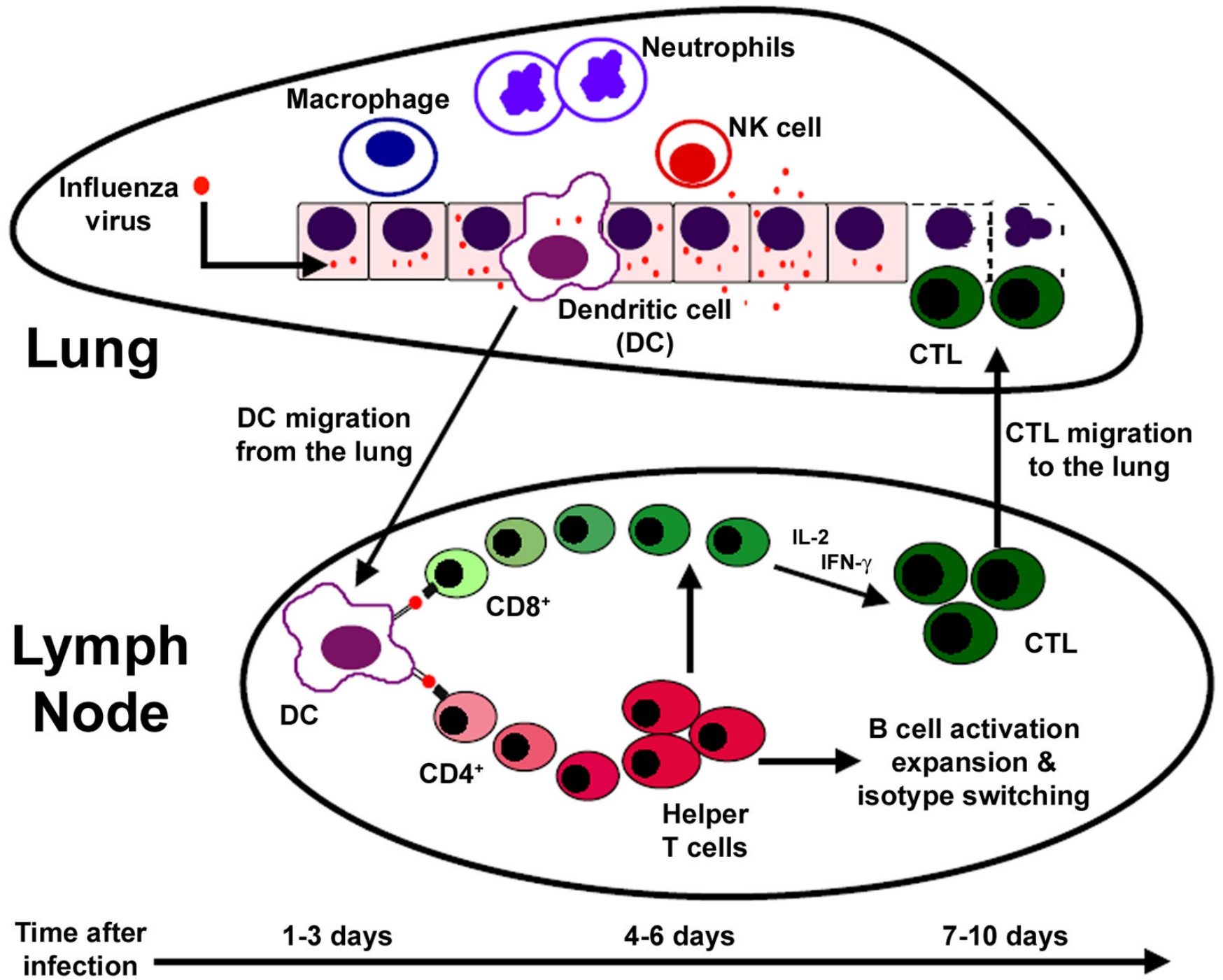

Figure 1.

Host immune response to influenza virus infection. 
A.

Neutrophils

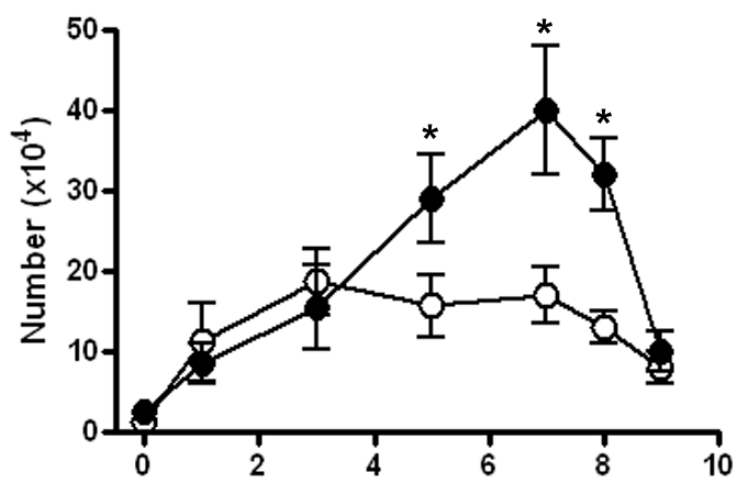

C. $\mathrm{NP}_{366-374} / \mathrm{D}^{\mathrm{b}+} \mathrm{CD} 8^{+} \mathrm{T}$ cells Lung

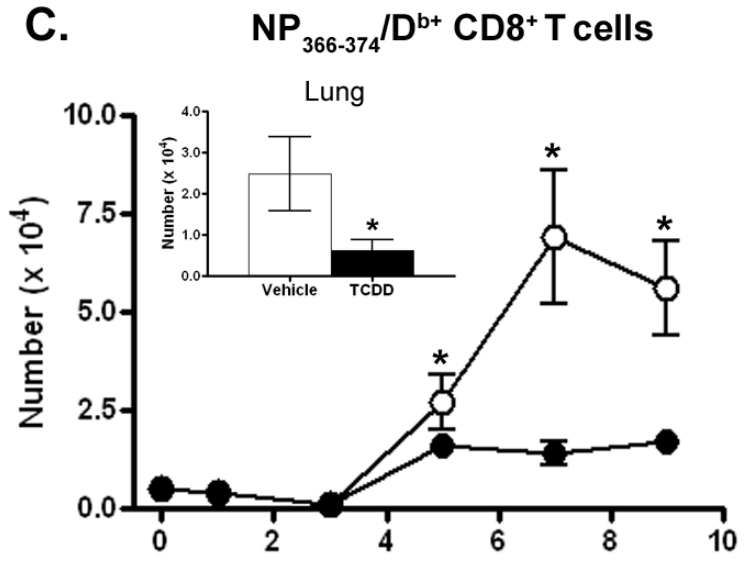

Figure 2. between treatment groups $(n=4-8 \mathrm{mice} /$ group/day; $\mathrm{p} \leq 0.05)$.
B.

IFN- $\gamma$ levels

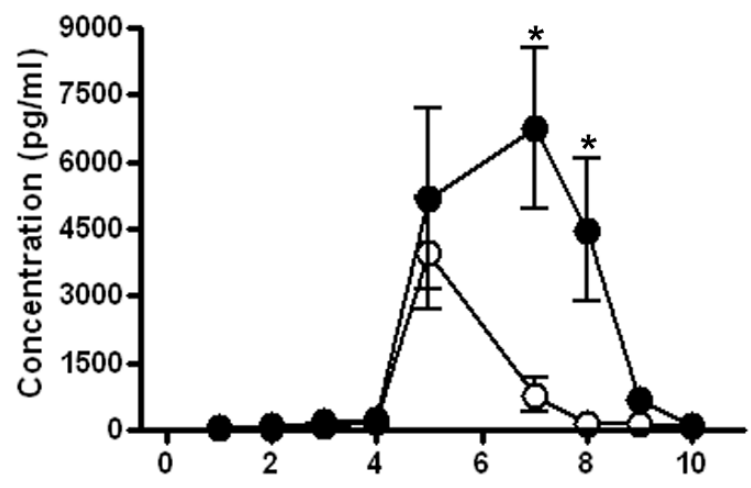

D. IFN- $\gamma^{+}$CD8 ${ }^{+} T$ cells

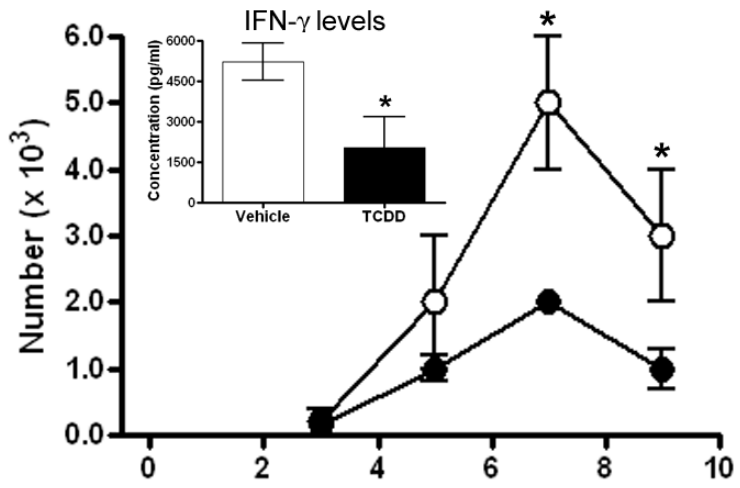

Day Relative to Infection

AhR activation modulates innate and adaptive immune responses in the lung and mediastinal lymph node (MLN). Mice were treated (p.o.) with $10 \mu \mathrm{g} / \mathrm{kg}$ TCDD (closed circles) or peanut oil vehicle control (open circles) and intranasally-infected with influenza A virus (x31, H3N2) one day later. Mice were sacrificed on the indicated days relative to infection; day 0 refers to uninfected mice. (A) The average number of neutrophils in lung airways was determined by differential cell counts. (B) The average level of IFN- $\gamma$ in bronchoalveolar lavage fluid was measured by ELISA. (C) The average number of influenza virus nucleoprotein (NP)-specific $\left(\mathrm{NP}_{366-374} / \mathrm{D}^{\mathrm{b}+}\right) \mathrm{CD}^{+} \mathrm{T}$ cells in the $\mathrm{MLN}$ was determined by flow cytometry. TCDD treatment also reduces the number of $\mathrm{NP}_{366-374} / \mathrm{D}^{\mathrm{b}+} \mathrm{CD} 8^{+} \mathrm{T}$ cells in the lung $(\mathbf{C}$, inset, day 8 post infection shown). (D) The average number of IFN- $\gamma^{+} \mathrm{CD}^{+} \mathrm{T}$ cells in the MLN was determined by flow cytometry. TCDD treatment also reduces the overall level of IFN- $\gamma$ produced by these cells (D, inset shows IFN- $\gamma$ levels from MLN cells 8 days after infection), as determined by ELISA. Error bars indicate SEM; * denotes a statistical significant difference 
MLN

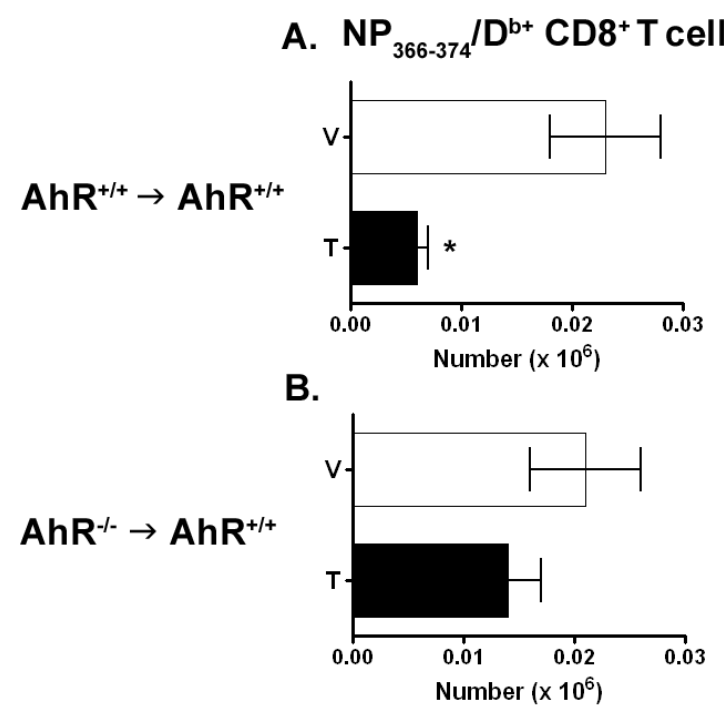

C. Neutrophils

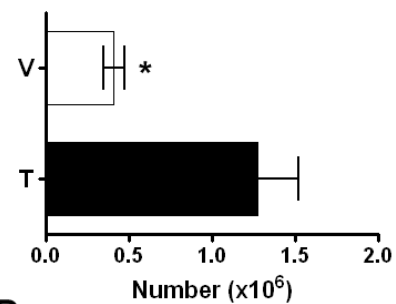

D.

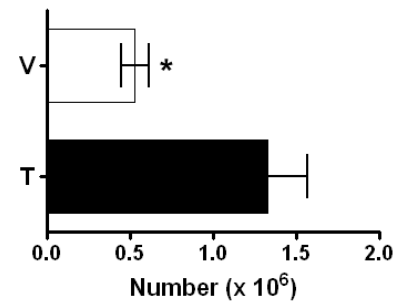

LUNG

E. IFN $-\gamma^{+}$cells

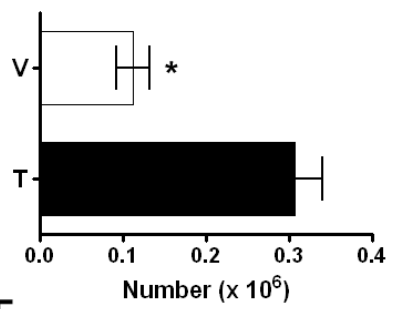

F.

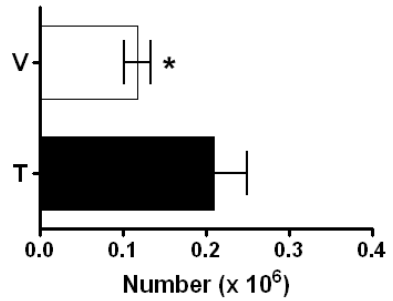

Figure 3.

AhR activation has direct and indirect effects on bone marrow-derived cells. Bone marrow chimeric mice were generated by reconstituting irradiated B6.CD45.1 $\mathrm{AhR}^{+/+}$mice with bone marrow from either B6.CD45.2 $\mathrm{AhR}^{+/+}\left(\mathrm{AhR}^{+/+} \rightarrow \mathrm{AhR}^{+/+}\right)$or B6.CD45.2 $\mathrm{AhR}^{-/-}\left(\mathrm{AhR}^{-/-}\right.$ $\rightarrow \mathrm{AhR}^{+/+}$) mice. $4-5$ weeks after transplantation, mice were treated with $10 \mu \mathrm{g} / \mathrm{kg}$ TCDD (T) or vehicle control (V) and infected with influenza virus as described in Figure 2. Mice were sacrificed $7(\mathbf{C}-\mathbf{F})$ or $9(\mathbf{A}, \mathbf{B})$ days after infection. Bars represent the average number $( \pm$ SEM) of cells that are CD45.2+ (donor-derived), as determined by flow cytometry and show analyses of $\mathrm{NP}_{344-374} / \mathrm{D}^{\mathrm{b}}$-specific CD8 ${ }^{+} \mathrm{T}$ cells in the $\mathrm{MLN}(\mathbf{A}, \mathbf{B})$, and CD45.2 ${ }^{+} \mathrm{Gr}-1^{+}$cells (neutrophils, C,D) and CD45.2 $2^{+} \mathrm{IFN}-\gamma^{+}$cells $(\mathbf{E}, \mathbf{F})$ in the lung. IFN- $\gamma^{+}$cells were detected by intracellular staining after in vitro re-stimulation of lung-derived immune cells. $*$ denotes a statistical significant difference between treatment groups $(n=6-8 \mathrm{mice} / \mathrm{group} / \mathrm{day} ; \mathrm{p} \leq 0.05)$. 